\title{
Analisa Pengaruh Variasi Komposisi Gas Pelindung Terhadap Hasil Pengelasan Gmaw-Short Circuit dengan Penggunaan Mesin Khusus Regulated Metal Deposition (RMD)
}

\author{
Zakwan Hilmy1, Nur Syahroni2, Yoyok S. Hadiwidodo3 \\ 1 Mahasiwa Teknik Kelautan, Fakultas Teknologi Kelautan, ITS Surabaya \\ 2\&3 Staf Pengajar Teknik Kelautan ITS, FTK ITS Surabaya \\ e-mail: zakwanhilmy13@gmail.com
}

\begin{abstract}
Abstrak
Salah satu faktor yang menentukan hasil pengelasan adalah gas pelindung (Shielding Gas). Jenis dan komposisi gas pellindung pada pengelasan memberikan hasil yang berbeda antara satu dengan lainnya. Moda transfer GMAW- short circuit sering tidak dilakukan karena memiliki tingkat kesukaran yang tinggi. Oleh sebab itu perusahaan listrik Miller membuat terobosan dengan menciptakan RMD (Regulated Metal Deposition). Oleh karena itu diadakan penelitian yang bertujuan mengetahui bagaimana pengaruh variasi gas pelindung elektroda yang digunakan pada proses pengelasan GMAW dengan menggunakan mesin RMD (Regulated Metal Deposition) dengan transfer moda secara short circuit terhadap hasil pengelasan pipa baja ASTM A106 dengan komposisi $\mathrm{Ar}+\mathrm{CO}_{2}(90 \%+10 \%, 80 \%+20 \%, 75 \%+15 \%$, $0 \%+100 \%$ ) pada posisi Flat, horizontal, vertical, dan overhead di bagian root. Analisa terhadap hasil pengelasan menunjukan bahwa kriteria yang diamati seperti hardness, level spatter, tebal weld metal, serta bentuk dan konsistensi hasil pengelasan (weld bead) mengalami perubahan terhadap penambahan komposisi gas $\mathrm{CO}_{2} .100 \%$ gas $\mathrm{CO}_{2}$ menghasilkan nilai kekerasan terendah yaitu $186.46 \mathrm{HV}$ dan level spatter tertinggi yaitu $12.27 \%$. Bentuk weld bead yang tidak konsisten dihasilkan seiring bertambahnya gas $\mathrm{CO}_{2}$, hal ini karena busur las yang dihasilkan menjadi tidak stabil sehingga menyulitkan welder.
\end{abstract}

Kata Kunci: GMAW-short circuit, gas pelindung argon, baja ASTM 106, gas pelindung $\mathrm{CO}_{2,}$, regulated metal deposition

\section{PENDAhuluan}

Pengelasan adalah proses penyambungan logam atau non logam yang dilakukan dengan memanaskan material yang akan disambung hingga temperatur las yang dilakukan secara: dengan atau tanpa menggunakan tekanan (pressure), hanya dengan tekanan (pressure), atau dengan atau tanpa menggunakan logam pengisi (filler). Sebagai teknik penyambungan logam pengelasan pada dasarnya merupakan ikatan metalurgi pada sambungan antar logam paduan yang dilaksanakan pada keadaan lumer atau cair [1].

Gas pelindung adalah komponen penting pada proses pengelasan dimana gas berperan sebagai pelindung pada weld metal agar tidak terjadi interaksi dengan atmosfer sekitar. Tiap-tiap gas pelindung memberikan hasil yang berbeda pada hasil pengelasan. Hal ini menyebabkan gas campur (mixing gas) argon dan $\mathrm{CO}_{2}$ mulai diminati [1] karena memberikan hasil pengelasan yang lebih optimal.

Proses pengelasan GMAW memiliki banyak moda transfer seperti spray, pulse, globular, dan short circuit. Moda transfer yang biasanya tidak digunakan oleh perusahaan fabrikasi dan pengelasan dalah short circuit karena memberikan resiko tinggi terhadap spatter dan busur yang tidak stabil sehingga berdampak pada menurunnya tingkat efesiensi pekerjaan karena membutuhkan perbaikan dan proses grinding ekstra pada spatter. Untuk mengatasi masalah tersebut maka dilakukan pematenan software oleh Miller yaitu Regulated Metal Deposition (RMD) untuk mengatasi permasalah ketika welder menggunakan moda transfer short circuit pada pengelasan GMAW.

Pada penelitian ini akan dilakukan pengelasan GMAW dengan menggunakan mesin RMD (Regulated Metal Deposition) dengan transfer moda secara short circuit terhadap hasil pengelasan pipa baja ASTM A106 dengan komposisi $\mathrm{Ar}+\mathrm{CO}_{2}$ $(90 \%+10 \%, 80 \%+20 \%, 75 \%+15 \%, 0 \%+100 \%)$ pada posisi Flat, horizontal, vertical, dan overhead di bagian root untuk melihat pengaruh dari penambahan persentase karbon dioksida terhadap hasil pengelasan. 


\section{TINJAUAN PUSTAKA}

\subsection{Pengelasan}

Pengelasan merupakan salah satu cara menyambungkan dua buah logam dengan cara pemanasan [2].Pengelasan adalah teknik penyambungan logam dengan cara mencairkan sebagian logam induk dan logam pengisi dengan dan atau menggunakan tekanan untuk mendapatkan sebuah sambungan yang kontinyu.

\subsection{Pengelasan GMAW (Gas Metal Arc Welding)}

Gas metal arc welding (GMAW) adalah proses pengelasan sebagai upaya penyambungan dua buah material logam dengan menggunakan busur listrik (electrical arc) yang tercipta akibat interaksi wire (elektroda) dengan benda kerja (logam yang akan dilas) [3]. Selama proses pengelasan berlangsung, gas pelindung akan disalurkan secara otomatis dari tabung gas menuju gas nozzle yang terdapat pada welding gun yang kemudian akan disemprotkan untul melindungi weld metal.

\subsection{Penjelasan Tentang Short Circuit}

Short circuit adalah salah satu jenis moda transfer pada pengelasan GMAW yang menggunakan arus dan ampere yang rendah untuk menciptakan busur las yang pendek (15-22 V dan 50-220 A) [3]. Droplet atau lelehan elektroda yang dihasilkan pada pengelasan short circuit memiliki tingkat viskositas yang tinggi serta laju transfer hingga 50-200 droplet per detik. Metode short circuit memberikan keuntungan pada nilai heat input yang tergolong rendah sehingga menghasilkan weld metal yang cukup tipis dan memiliki tingkat distorsi yang rendah dan cepat mendingin [4].

\subsection{Penjelasan Gas Pelindung (Shielding Gas)}

Gas pelindung adalah komponen dari proses pengelasan yang memiliki fungsi melindungi proses pengelasan weld metal dan weld pool) dari kontaminasi udara sekitar (oksigen dan nitrogen). Argon memiliki potensial ionisasi yang rendah sehingga bususr las yang dihasilkan stabil serta sedikit spatter. Karbon dioksida menghasilkan konduktivitas termal yang tinggi dan penetrasi yang dalam hal ini dikarenakan karbon dioksida memiliki potensial ionisasi yang tinggi sehingga busur yang dihasilkan tidak stabil dan menimbulkan banyak spatter [5]. Perhatikan Tabel 1 pada tabel tersebut dapat dilihat karakteristik pada jenis-jenis gas pelindung [6].

Tabel 1 Karakteristik dari jenis gas pelindung

\begin{tabular}{|c|c|c|c|c|c|c|c|}
\hline \multirow[t]{2}{*}{ GAS } & \multirow[t]{2}{*}{$\begin{array}{l}\text { CHEMIICAL } \\
\text { SYMBOL }\end{array}$} & \multirow[t]{2}{*}{$\begin{array}{l}\text { MOLECULAR } \\
\text { WEIGHI }\end{array}$} & \multirow[t]{2}{*}{$\begin{array}{l}\text { SPECIFIC } \\
\text { GRAVITY }^{(\lambda)}\end{array}$} & \multicolumn{2}{|c|}{ DENSITY } & \multicolumn{2}{|c|}{$\begin{array}{l}\text { IONIZATION } \\
\text { POTENTIAL }\end{array}$} \\
\hline & & & & $\mathrm{g} / \mathrm{ft}^{3}$ & g/ 1 & $a j^{(8)}$ & $\mathrm{eV}$ \\
\hline ARGON & AR & 39.95 & 1.38 & 0.1114 & 1.784 & 2.52 & 15.7 \\
\hline $\begin{array}{l}\text { CARBON } \\
\text { DIOXIDE }\end{array}$ & $\mathrm{CO}_{2}$ & 44.01 & 1.53 & 0.1235 & 1.978 & 2.26 & 14.4 \\
\hline HELIUM & $\mathrm{HE}$ & 4.00 & 0.1368 & 0.0111 & 0.178 & 3.92 & 24.5 \\
\hline HYDROGEN & $\mathrm{H}_{2}$ & 2.016 & 0.0695 & 0.0056 & 0.090 & 2.16 & 13.5 \\
\hline NITROGEN & $\mathrm{N}_{2}$ & 28.01 & 0.967 & 0.782 & 12.5 & 2.32 & 14.5 \\
\hline OXYGEN & $\mathrm{O}_{2}$ & 32.00 & 1.105 & 0.0892 & 1.43 & 2.11 & 13.2 \\
\hline
\end{tabular}

\subsection{Penjelasan Spatter}

Spatter adalah percikan yang terjadi selama proses pengelasan. Spatter disebabkan pengaturan arus yang dan gas pelindung yang tidak tepat. Semakin besar kadar $\mathrm{CO}_{2}$ maka spatter akan semakin banyak namun biaya produksi akan berkurang sedangkan penggunaan Argon dapat mereduksi tingkat spatter namun biaya produksi akan bertambah karena gas Argon lebih mahal.

\subsection{Penjelasan Regulated Metal Deposition (RMD)}

Regulated Metal Deposition (RMD) adalah software yang telah dipatenkan oleh Miller. Sistem kerja dari RMD adalah memodifikasi cara kerja dari proses pengelasan GMAW dengan mode transfer short circuit. Arus dan tegangan pada elektroda selama proses pengelasan dikontrol dengan detail (perhatikan Gambar 1) [7] sehingga tingkat kestabilan arus pada elektroda terkontrol.

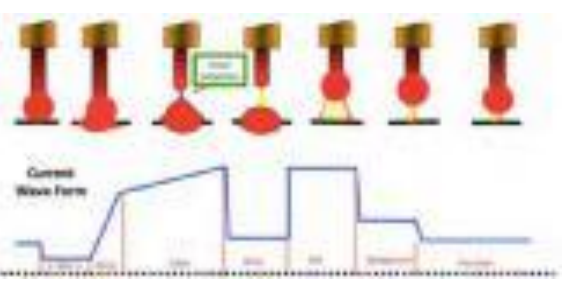

Gambar 1 Prinsip kerja RMD (Dokumen SIKB-STT vs RMD Welding Process Investigation, 2015)

\subsection{Penjelasan Kekerasan (Hardness)}


Pada hasil pengelasan terdapat beberapa metode pengujian nilai kekerasan material, salah satunya adalah Vickers hardness testing. Metode ini menggunakan luasan yang terbetuk oleh tekanan mesin dengan gaya tertentu yang kemudian dikalkulasi menggunakan computer sehingga didapat nilai kekerasan material tersebut [8].

\section{METODE PENELITIAN}

\subsection{Material Properties}

Properties dari material ditunjukan oleh Tabel 2 berikut.

Tabel 2 Properties material las

\begin{tabular}{|l|l|}
\hline Diameter pipa & 8 Inch \\
\hline Jenis material & ASTM A106 \\
\hline Jenis elektroda & REVOFIL 80S-Ni1 \\
\hline Diameter elektroda & $1 \mathrm{~mm}$ \\
\hline Ketebalan material & $12.7 \mathrm{~mm}$ \\
\hline Panjang jalur las & $150 \mathrm{~mm}$ per position \\
\hline Bevel & $30^{\circ}$ tiap sisi $\left(60^{\circ}\right.$ total keseluruhan $)$ \\
\hline Gap & $3-4 \mathrm{~mm}$ \\
\hline
\end{tabular}

Pipa yang akan dilas berjumlah 3 pipa per komposisi gas dengan kecepatan elektroda yang sama yaitu 105 IPM

\subsection{Proses Pengelasan}

Pengelasan dilakukan pada 4 posisi, yaitu flat, vertical, overhead, dan horizontal. Tiap-tiap komposisi gas dilakukan pengelasan sebanyak 3 kali (3 pipa) pada bagian root phase.

\subsection{Pengecekan Hasil Pengelasan Secara Visual}

Pengecekan hasil pengelasan secara visual untuk menganalisa bentuk weld bead (convex. Concave, flat). Pengecekan diikuti dengan proses mempersentasekan tingkat konsisten dari ketinggian weld bead pada bagian outer dan penghitungan dengan menggunakan welding gauge pada bagian root penetration.

\subsection{Proses Penghitungan Jumlah Spatter}

Perhitungan jumlah spatter dilakukan secara manual dengan mengelompokkan spatter pada beberapa kelompok berdasarkan diameter (lihat Gambar 2).

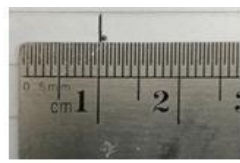

(a)

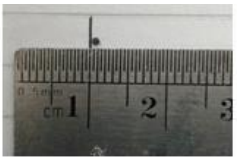

(b)

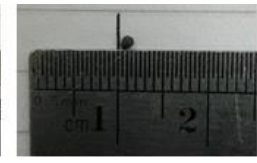

(c)

Gambar 2 Contoh pengelompokan spatter berdasarkan diameter, $\leq 1.3 \mathrm{~mm}$ (gambar a), $1.3 \mathrm{~mm}-2 \mathrm{~mm}$ (gambar b), dan $\geq 2 \mathrm{~mm}$ (gambar c)

\subsection{Uji Kekerasan}

Uji kekerasan yang dilakukan adalah Vickers hardness testing yang terdapat di PT. Hi-Test Batam. Titik pengujian berada pada bagian base metal, HAZ, dan weld metal. Posisi pengelasan yang diuji adalah posisi flat dan overhead (posisi start-stop).

\subsection{Analisa Data}

Setelah data terkumpul selanjutnya dilakukan analisa data. Adapun yang dianalisa adalah sebagai berikut:

1. Analisa profil hasil pengelasan secara visual dilakukan untuk melihat bentuk weld bead dan tinggi root pass yang dihasilkan.

2. Penghitungan jumlah spatter dilakukan secara manual dengan pengelompokan jumlah spatter berdasarkan diameter dan membandingkan berat total spatter terhadap weld deposition.

3. Analisa data kekerasan untuk melihat apakah terdapat perbedaan nilai kekerasan yang signifikan pada hasil pengelasan tiap-tiap komposisi gas

4. Menghitung biaya yang dikeluarkan terhadap gas pelindung yang digunakan. 
5. Pemberian nilai/score (range 1-4) untuk tiap-tiap hasil analisa sebagai acuan dalam memilih komposisi gas mana yang memberikan hasil pengelasan yang baik (secara keseluruhan).

\section{HASIL DAN PEMBAHASAN}

\subsection{Analisa Profil Weld Bead}

Persentase konsisten tidaknya pada weld bead hasil pengelasan dilihat dari bentuk weld bead (ketinggian weld bead) pada tiap-tiap posisi pengelasan dengan persentase 0\%-95\%). Adapun hasil analisa ditampilkan pada Tabel 3 berikut

Tabel 3 Persentase tingkat konsistensi weld bead

\begin{tabular}{|c|c|c|c|c|c|}
\hline \multirow{3}{*}{$\begin{array}{c}\text { Komposisi } \\
\text { Gas } \\
(\mathrm{Ar}+\mathrm{CO} 2)\end{array}$} & \multirow{3}{*}{ Posiai } & \multicolumn{2}{|c|}{$\begin{array}{l}\text { Persentase Tingkat Konsisten Weld Bead } \\
(\%)\end{array}$} & \multirow{3}{*}{$\begin{array}{l}\text { Rata-Rata Per } \\
\text { Pogiai }\end{array}$} & \multirow{3}{*}{ Rata-rata Total } \\
\hline & & Root Pass Outer Profile & Root Pass Penetration Profile & & \\
\hline & & Persentase & Persentase & & \\
\hline \multirow{4}{*}{$90 \%+10 \%$} & $\mathrm{H}$ & $90 \%$ & $90 \%$ & $90 \%$ & \multirow{4}{*}{$90 \%$} \\
\hline & F & $90 \%$ & $95 \%$ & $93 \%$ & \\
\hline & $\mathrm{v}$ & $90 \%$ & $95 \%$ & $93 \%$ & \\
\hline & $\mathrm{OH}$ & $85 \%$ & $85 \%$ & $85 \%$ & \\
\hline \multirow{4}{*}{$80 \%+20 \%$} & $\mathrm{H}$ & $85 \%$ & $90 \%$ & $88 \%$ & \multirow{4}{*}{$87 \%$} \\
\hline & $\mathrm{F}$ & $80 \%$ & $90 \%$ & $85 \%$ & \\
\hline & $\mathrm{v}$ & $85 \%$ & $90 \%$ & $88 \%$ & \\
\hline & $\mathrm{OH}$ & $85 \%$ & $90 \%$ & $88 \%$ & \\
\hline \multirow{4}{*}{$75 \%+25 \%$} & $\mathrm{H}$ & $85 \%$ & $80 \%$ & $83 \%$ & \multirow{4}{*}{$83 \%$} \\
\hline & $\mathrm{F}$ & $80 \%$ & $85 \%$ & $83 \%$ & \\
\hline & $\mathrm{v}$ & $80 \%$ & $80 \%$ & $80 \%$ & \\
\hline & $\mathrm{OH}$ & $80 \%$ & $90 \%$ & $85 \%$ & \\
\hline \multirow{4}{*}{$100 \% \mathrm{CO} 2$} & $\mathrm{H}$ & $75 \%$ & $80 \%$ & $78 \%$ & \multirow{4}{*}{$71 \%$} \\
\hline & $\mathrm{F}$ & $75 \%$ & $75 \%$ & $75 \%$ & \\
\hline & $\mathrm{v}$ & $80 \%$ & $70 \%$ & $75 \%$ & \\
\hline & $\mathrm{OH}$ & $50 \%$ & $60 \%$ & $55 \%$ & \\
\hline
\end{tabular}

Pengukuran dilakukan pada 4 titik jalur pengelasan (per posisi atau setiap $37.7 \mathrm{~mm}$ ). Hasil pengukuran disajikan dalam bentuk Tabel 4 sebagai berikut:

Tabel 4 Ketinggian root pass penetration

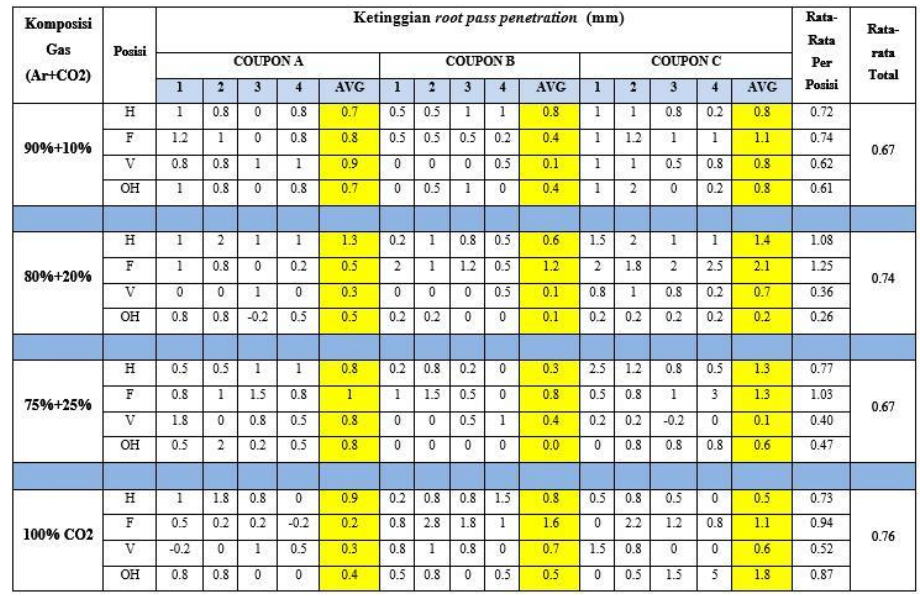

Pada Tabel 4 terlihat bahwa ketinggian root pass penetration tiap-tiap komposisi gas pelindung tergolong baik (sesuai AWS maksimum ketinggian tidak lebih dari $3 \mathrm{~mm}$ ).

\subsection{Analisa Tingkat Spatter}

Perhitungan spatter dilakukan secara manual dan dilakukan beberapa kali sebagai validasi. Hasil perhitungan digambarkan dalam bentuk grafik pada Gambar 4:

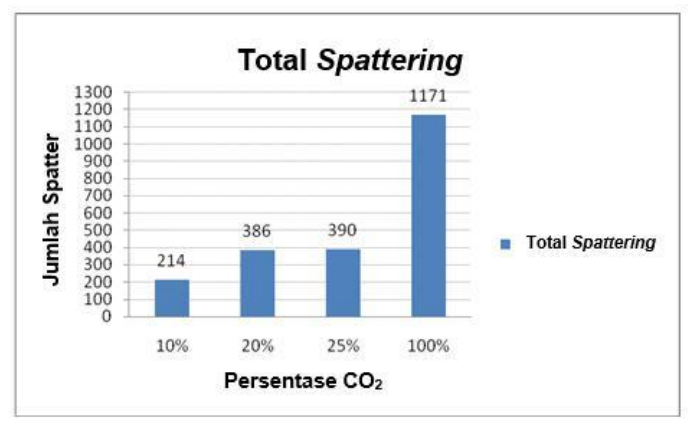

Gambar 4 Grafik total spattering 
Dengan menggunakan data Tabel 4 dapat dicari persentase tingkat spatter dengan menggunakan persamaan dibawah ini:

\section{$\underline{\left(\Pi \times \mathbf{r}^{3} \times \text { pcs } \times \text { Jumlah Spatter }\right)}$}

\section{Weld deposition}

Dimana:

$\Pi$

$\mathrm{r} \quad$ = Jari-jari spatter $(\mathrm{mm})$

pcs $\quad=$ Densitas carbon steel $(0.00785 \mathrm{~g} / \mathrm{mm})$

DR = Weld deposition rate $(334.335 \mathrm{~g})$ per komposisi gas

* Jari-jari spatter yang dihitung $1.3 \mathrm{~mm}, 2 \mathrm{~mm}$, and $2.3 \mathrm{~mm}$

Deposition rate dihitung menggunakan rumus :

\section{$\mathrm{DR}=1 / 2 \times \mathbf{a} \times \mathbf{t} \times \mathbf{l} \times \boldsymbol{\rho c s}$}

Dimana:

$$
\begin{aligned}
& \mathrm{DR}=\text { Weld deposition rate } \\
& \mathrm{T} \quad=\text { Tebal plat }(12.7 \mathrm{~mm}) \\
& \mathrm{t}=(\mathrm{T}-\mathrm{t} 1)+\mathrm{t} 2=5.94 \mathrm{~mm} \\
& \text { a } \quad=\text { Lebar weld bead }(3.98 \mathrm{~mm}) \\
& 1=\text { Panjang jalur las }(600 \mathrm{~mm}) \\
& \rho_{\mathrm{cs}} \quad=\text { Densitas carbon steel } \\
& =1 / 2 \times 3.98 \times 5.94 \times 600 \times 0.00785 \\
& =111.4453 \mathrm{~g} \text { per coupon }
\end{aligned}
$$

\begin{tabular}{|c|c|c|c|c|c|}
\hline $\begin{array}{l}\text { Komposisi } \\
\text { Gas } \\
(\mathrm{Ar}+\mathrm{CO} 2)\end{array}$ & $\begin{array}{c}\text { Diameter } \\
\text { Spatter }\end{array}$ & $\begin{array}{c}\text { Total } \\
\text { Kuantitas } \\
\text { Spatter per } \\
\text { Diameter }\end{array}$ & $\begin{array}{c}\begin{array}{c}\Pi \times \mathbf{r}^{3} \times \rho_{\text {carbon stel }} \mathbf{x} \\
\text { Jumlah Spatter })\end{array} \\
\text { Weld deposition }\end{array}$ & $\begin{array}{c}\text { Persentase } \\
\text { Spattering per } \\
\text { Diameter }\end{array}$ & $\begin{array}{c}\text { Persentase } \\
\text { Spattering Total } \\
\text { per Komposisi } \\
\text { Gas }\end{array}$ \\
\hline \multirow{3}{*}{$90 \%+10 \%$} & $\leq 1.3 \mathrm{~mm}$ & 204 & 0.0130 & $1.30 \%$ & \multirow{3}{*}{$1.54 \%$} \\
\hline & $1.3 \mathrm{~mm}-1.5 \mathrm{~mm}$ & 9 & 0.0021 & $0.21 \%$ & \\
\hline & $\geq 2 \mathrm{~mm}$ & 1 & 0.0004 & $0.04 \%$ & \\
\hline \multirow{3}{*}{$80 \%+20 \%$} & $\leq 1.3 \mathrm{~mm}$ & 330 & 0.0210 & $2.10 \%$ & \multirow{3}{*}{$3.53 \%$} \\
\hline & \begin{tabular}{|l}
$1.3 \mathrm{~mm}-1.5 \mathrm{~mm}$ \\
\end{tabular} & 45 & 0.0104 & $1.04 \%$ & \\
\hline & $\geq 2 \mathrm{~mm}$ & 11 & 0.0039 & $0.39 \%$ & \\
\hline \multirow{3}{*}{$75 \%+25 \%$} & $\leq 1.3 \mathrm{~mm}$ & 326 & 0.0207 & $2.07 \%$ & \multirow{3}{*}{$3.78 \%$} \\
\hline & $1.3 \mathrm{~mm}-1.5 \mathrm{~mm}$ & 45 & 0.0104 & $1.04 \%$ & \\
\hline & $\geq 2 \mathrm{~mm}$ & 19 & 0.0067 & $0.67 \%$ & \\
\hline \multirow{3}{*}{$100 \% \mathrm{CO} 2$} & $\leq 1.3 \mathrm{~mm}$ & 933 & 0.0593 & $5.93 \%$ & \multirow{3}{*}{$12.27 \%$} \\
\hline & $1.3 \mathrm{~mm}-1.5 \mathrm{~mm}$ & 169 & 0.0391 & $3.91 \%$ & \\
\hline & $\geq 2 \mathrm{~mm}$ & 69 & 0.0243 & $2.43 \%$ & \\
\hline
\end{tabular}

Untuk mendapatkan Weld deposition per komposisi gas maka:

$$
\begin{aligned}
\mathrm{DR} & =111.4453 \times 3 \\
& =334.335 \mathrm{~g}
\end{aligned}
$$

Dengan menggunakan persamaan di atas maka dapat dibuat tabel perhitungan persentase spattering pada Tabel 5:

Tabel 5 Persentase spattering

4.3 Analisa Tebal Weld Deposition dan Nilai Kekerasan

Analisa tebal weld bead dilakukan dengan menggunakan macroetch dan foto macro (lihat Gambar 6).

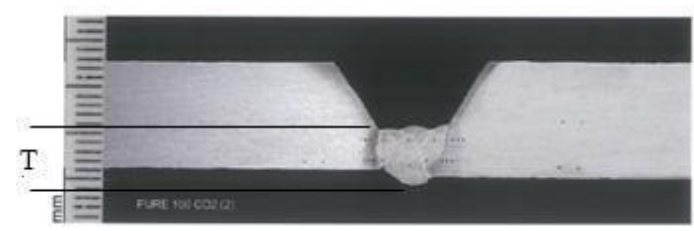


Berdasarkan hasil foto macro dapat dihitung ketebalan dari weld deposition yang kemudian dirangkum pada Tabel 6 berikut:

Tabel 6 Tabel ketebalan weld deposition

\begin{tabular}{|c|c|c|c|c|c|}
\hline $\begin{array}{c}\text { Komposisi } \\
\text { Gas } \\
\left(\mathrm{Ar}+\mathrm{CO}_{2}\right)\end{array}$ & Posisi pengelasan & $\begin{array}{c}\text { Tebal } \\
\text { Weld } \\
\text { Deposition } \\
\text { (T) }\end{array}$ & $\begin{array}{c}\text { Posisi } \\
\text { Pengelasan }\end{array}$ & $\begin{array}{c}\text { Tebal Weld } \\
\text { Depposition } \\
\text { per Posisi }\end{array}$ & $\begin{array}{c}\text { Tebal Weld } \\
\text { Deposition } \\
\text { per } \\
\text { Komposisi } \\
\text { Gas }\end{array}$ \\
\hline \multirow{3}{*}{$90 \%+10 \%$} & $\begin{array}{c}\text { Flat-coupon A } \\
\text { Overhead-coupon A }\end{array}$ & $\begin{array}{l}4.5 \mathrm{~mm} \\
2.5 \mathrm{~mm}\end{array}$ & FLAT & $4 \mathrm{~mm}$ & \multirow{3}{*}{$3.4 \mathrm{~mm}$} \\
\hline & $\begin{array}{c}\text { Overhead-coupon A } \\
\text { Flat-coupon B }\end{array}$ & $4 \mathrm{~mm}$ & & & \\
\hline & Overhead-coupon B & $3 \mathrm{~mm}$ & OVEKHEAD & $2.8 \mathrm{~mm}$ & \\
\hline \multirow{3}{*}{$80 \%+20 \%$} & Flat-coupon A & $4 \mathrm{~mm}$ & FLAT & & \multirow{3}{*}{$3.6 \mathrm{~mm}$} \\
\hline & Overhead-coupon $\mathrm{A}$ & $4.5 \mathrm{~mm}$ & & & \\
\hline & $\begin{array}{c}\text { Flat-coupon B } \\
\text { Overhead-coupon B }\end{array}$ & $3 \mathrm{~mm}$ & OVERHEAD & $3.8 \mathrm{~mm}$ & \\
\hline \multirow{3}{*}{$75 \%+25 \%$} & Flat-coupon A & $2.5 \mathrm{~mm}$ & FLAT & & \multirow{3}{*}{$2.6 \mathrm{~mm}$} \\
\hline & Overhead-coupon $\mathrm{A}$ & $2.5 \mathrm{~mm}$ & & $2.8 \mathrm{~mm}$ & \\
\hline & Flat-coupon B & $\frac{3 \mathrm{~mm}}{3 \mathrm{~mm}}$ & OVERHEAD & $2.8 \mathrm{~mm}$ & \\
\hline \multirow{3}{*}{$100 \% \mathrm{CO} 2$} & Flat-coupon A & $3 \mathrm{~mm}$ & & $3.5 \mathrm{~mm}$ & \multirow{3}{*}{$4 \mathrm{~mm}$} \\
\hline & Overhead-coupon A & $5 \mathrm{~mm}$ & FEAI & & \\
\hline & Flat-coupon B & $4 \mathrm{~mm}$ & OVERHEAD & $4.5 \mathrm{~mm}$ & \\
\hline
\end{tabular}

Pada penelitian ini pengujian Vickers hardness test dilakukan pada 2 line dengan 2 titik (per line) pengujian pada BM (base metal) dan 3 titik (per line) pada HAZ (heat affected zone) dan WM (weld metal) sesuai ASTM. Nilai kekerasan yang ditampilakan pada table 7 berikut:

Tabel 7 Nilai kekerasan (tabel a) dan Nilai kekerasan rata-rata pada weld bead dan HAZ (tabel b)

\begin{tabular}{|c|c|c|c|c|c|c|c|c|c|c|}
\hline \multirow{3}{*}{$\begin{array}{c}\text { KOMPOSISI } \\
\text { GAS } \\
(\mathrm{Ar}+\mathrm{CO} 2)\end{array}$} & \multirow{3}{*}{$\begin{array}{c}\text { POSISI } \\
\text { PENGELASAN }\end{array}$} & \multicolumn{9}{|c|}{ NILAI KEKERASAN (HV 10) } \\
\hline & & \multicolumn{3}{|c|}{ BASE METAL } & \multicolumn{3}{|c|}{ HAZ } & \multicolumn{3}{|c|}{ WELDMETAL } \\
\hline & & MIN & $\operatorname{Max}$ & $\begin{array}{l}\text { RATA- } \\
\text { RATA }\end{array}$ & MIN & $\operatorname{MAX}$ & $\begin{array}{l}\text { RATA- } \\
\text { RATA }\end{array}$ & MIN & $\operatorname{Max}$ & $\begin{array}{l}\text { RATA- } \\
\text { RATA }\end{array}$ \\
\hline \multirow{2}{*}{$90 \%+10 \%$} & FLAT & 145 & 164 & 154 & 180 & 270 & 199 & 211 & 238 & 220 \\
\hline & OVERHEAD & 138 & 162 & 149 & 173 & 241 & 192 & 216 & 226 & 214 \\
\hline \multirow{2}{*}{$80 \%+20 \%$} & FLAT & 143 & 167 & 151 & 171 & 235 & 186 & 210 & 230 & 213 \\
\hline & OVERHEAD & 141 & 163 & 151 & 178 & 243 & 181 & 213 & 227 & 214 \\
\hline \multirow{2}{*}{$75 \%+25 \%$} & FLAT & 148 & 166 & 157 & 171 & 246 & 202 & 203 & 270 & 228 \\
\hline & OVERHEAD & 130 & 159 & 149 & 160 & 233 & 186 & 202 & 227 & 211 \\
\hline \multirow{2}{*}{$100 \% \mathrm{CO} 2$} & FLAT & 144 & 193 & 162 & 183 & 248 & 192 & 196 & 206 & 195 \\
\hline & OVERHEAD & 144 & 192 & 161 & 175 & 235 & 196 & 177 & 190 & 178 \\
\hline
\end{tabular}

(a)

\begin{tabular}{|c|c|c|c|c|c|}
\hline \multirow[t]{2}{*}{$\begin{array}{c}\text { KOMPOSISI } \\
\text { GAS } \\
\text { (Ar+CO2) }\end{array}$} & \multirow[t]{2}{*}{$\begin{array}{l}\text { POSISI PENGELASAN } \\
\text { PER COUPON }\end{array}$} & \multicolumn{2}{|c|}{$\begin{array}{c}\text { RATA-RATA } \\
\text { PER COUPON } \\
\text { (HV) }\end{array}$} & \multicolumn{2}{|c|}{ RATA-RATA TOTAL } \\
\hline & & HAZ & Weld metal & HAZ & Weld metal \\
\hline \multirow{4}{*}{$90 \%+10 \%$} & Flat - coupon A & 217.33 & 222.33 & \multirow{4}{*}{195.63} & \multirow{4}{*}{216.63} \\
\hline & Overhead - coupon A & 200.92 & 221.17 & & \\
\hline & Flat - coupon B & 181.00 & 217.17 & & \\
\hline & Overhead - coupon B & 183.25 & 205.83 & & \\
\hline \multirow{4}{*}{$80 \%+20 \%$} & Flat - coupon A & 199.17 & 205.67 & \multirow{4}{*}{183.58} & \multirow{4}{*}{213.50} \\
\hline & Overhead - coupon A & 201.58 & 220.00 & & \\
\hline & Flat - coupon B & 173.58 & 220.67 & & \\
\hline & Overhead - coupon B & 160.00 & 207.67 & & \\
\hline \multirow{4}{*}{$75 \% 6+25 \%$} & Flat - coupon A & 206.50 & 216.50 & \multirow{4}{*}{193.75} & \multirow{4}{*}{219.50} \\
\hline & Overhead - coupon A & 208.25 & 214.00 & & \\
\hline & Flat - coupon B & 197.08 & 239.50 & & \\
\hline & Overhead - coupon B & 163.17 & 208.00 & & \\
\hline \multirow{4}{*}{$100 \% \mathrm{CO}_{2}$} & Flat - coupon A & 203.92 & 190.00 & \multirow{4}{*}{194.17} & \multirow{4}{*}{186.46} \\
\hline & Overhead - coupon A & 197.33 & 170.50 & & \\
\hline & Flat - coupon B & 180.33 & 200.50 & & \\
\hline & Orerhead - coupon B & 195.08 & 184.83 & & \\
\hline
\end{tabular}

(b)

Berdasarkan Tabel 7 (b) didapat grafik sebagaimana ditunjukan pada Gambar 7 berikut:
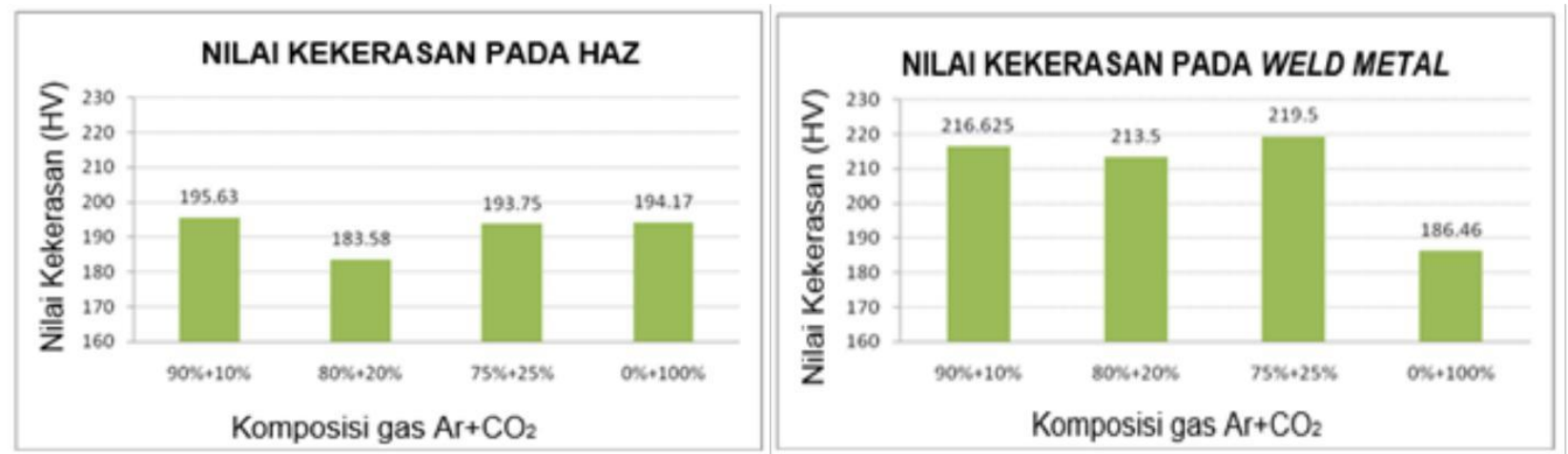

Gambar 7 Grafik nilai kekerasan pada HAZ dan Weld Metal

Bedasarkan Gambar 7 terlihat nilai kekerasan pada weld metal yang menggunakan komposisi gas $\mathrm{Ar}+\mathrm{CO}_{2}(90 \%+10 \%$, $80 \%+20 \%$, dan $75 \%+25 \%$ ) memiliki perbedaan nilai kekerasan yang tidak berbeda jauh (selisih \pm 3 HV), sedangkan penggunaan gas $\mathrm{CO}_{2}$ menghasilkan nilai kekerasan yang lebih kecil dibandingkan komposisi gas yang lainnya yaitu 186.46 .

\subsection{Analisa Biaya (Cost)}

Analisa biaya dilakukan dengan membandingkan biaya pengelasan perjam. Berikut data tabung gas yang digunakan pada penelitian ini (sumber harga dari Airliquid) ditunjukan Tabel 8: 
Tabel 8 Data tabung gas pelindung dan Perhitungan biaya

\begin{tabular}{|c|c|c|c|c|c|c|c|c|c|c|}
\hline \multirow[t]{2}{*}{ Gas cylinder } & \multirow[t]{2}{*}{ Volume (liter/cylinder) } & \multirow[t]{2}{*}{ Cost (per cylinder) } & Cost (per liter) & $\begin{array}{l}\text { Composition } \\
(\mathrm{Ar}+\mathrm{CO} 2)\end{array}$ & $\begin{array}{c}\text { Volume } \\
\text { Ar } \\
\text { (liter/min) }\end{array}$ & $\begin{array}{c}\text { Volume } \\
\mathrm{CO} 2 \\
\text { (liter/min) }\end{array}$ & $\begin{array}{c}\text { Cost Ar } \\
\text { (per minutes) }\end{array}$ & $\begin{array}{l}\text { Cost } \mathrm{CO}_{2} \\
\text { (per } \\
\text { minutes) }\end{array}$ & $\begin{array}{l}\text { Total cost per } \\
\text { minutes }\end{array}$ & $\begin{array}{c}\text { Total cost per } \\
\text { hour }\end{array}$ \\
\hline & & & \multirow[b]{2}{*}{0.0039} & $90 \%+10 \%$ & \begin{tabular}{|l|l}
16.98 \\
\end{tabular} & 1.89 & $\$ 0.07$ & $\$ 0.004$ & 50.07 & $\$ 4.18$ \\
\hline $\mathrm{Ar}$ & 10400 & 40.46 & & $80 \%+20 \%$ & 15.10 & 3.77 & $\$ 0.06$ & $\$ 0.007$ & $\$ 0.07$ & $\$ 3.96$ \\
\hline $\mathrm{CO} 2$ & 15000 & 28.75 & 0.0019 & $75 \%+25 \%$ & 14.15 & 4.72 & $\$ 0.06$ & $\$ 0.009$ & $\$ 0.06$ & $\$ 3.85$ \\
\hline & & & & $0 \%+100 \%$ & 0.00 & 18.87 & $\$$ & $\$ 0.036$ & $\$ 0.04$ & $\$ 2.17$ \\
\hline
\end{tabular}

Kecepatan aliran gas pelindung yang digunakan pada penelitian ini adalah 40 SCFH (18.87 lpm).

\subsection{Analisa Pemilihan Komposisi Gas Terbaik}

Adapun hasil penilaian dimasukkan pada Tabel 11 Score Card untuk semua penilaian sebagai berikut:

Tabel 10 Score card akhir

\begin{tabular}{|c|c|c|c|c|c|}
\hline \multirow{3}{*}{ Parameter } & \multirow{3}{*}{$\begin{array}{c}\text { Bobot } \\
\text { (\%) }\end{array}$} & \multicolumn{4}{|c|}{ Komposisi Gas (Argon $+\mathrm{CO}_{2}$ ) } \\
\hline & & $90 \%+10 \%$ & $80 \%+20 \%$ & $75 \%+25 \%$ & $0 \%+100 \%$ \\
\hline & & (Bobot X Score) & (Bobot X Score) & (Bobot X Score) & (Bobot X Score) \\
\hline Nilai Kekerasan & $30 \%$ & 0.9 & 0.9 & 0.9 & 0.6 \\
\hline \multicolumn{6}{|l|}{ Weld Bead : } \\
\hline $\begin{array}{l}\text { Tingkat } \\
\text { Konsistensi }\end{array}$ & $15 \%$ & 0.6 & 0.6 & 0.45 & 0.3 \\
\hline $\begin{array}{l}\text {-Tinggi Root Pass } \\
\text { Penetration }\end{array}$ & $10 \%$ & 0.4 & 0.4 & 0.4 & 0.4 \\
\hline $\begin{array}{l}\text {-Ketebalan Weld } \\
\text { Deposition }\end{array}$ & $10 \%$ & 0.3 & 0.3 & 0.2 & 0.4 \\
\hline Tingkat Spatter & $10 \%$ & 0.4 & 0.3 & 0.3 & 0.1 \\
\hline Biaya (cost) & $25 \%$ & 0.25 & 0.5 & 0.75 & 1 \\
\hline \multicolumn{2}{|l|}{ Total } & 2.85 & 3 & 3 & 2.8 \\
\hline
\end{tabular}

Berdasarkan hasil scoring dapat disimpulkan bahwa komposisi gas terbaik adalah $\mathrm{Ar}+\mathrm{CO}_{2}(80 \%+20 \%$ dan $75 \%+25 \%)$. $\mathrm{Hal}$ ini disebabkan tidak terdapatnya perbedaan yang signifikan pada penambahan $5 \% \mathrm{CO}_{2}$ pada hasil pengelasan.

\section{KESIMPULAN}

Adapun kesimpulan yang dapat diambil dari penelitian Tugas Akhir ini adalah :

1. Komposisi gas pelindung ( $\mathrm{Ar}$ dan $\mathrm{CO}_{2}$ ) menghasilkan bentuk weld bead yang berbeda-beda. Komposisi $\mathrm{Ar}+\mathrm{CO}_{2}$ $(90 \%+10 \%, 80 \%+20 \%$, dan $75 \%+25 \%)$ menghasilkan bentuk weld bead yang baik (convex dan flat) dikarenakan nyala bususr yang stabil. Sedangkan gas pelindung $\mathrm{CO}_{2} 100 \%$ menghasilkan bentuk weld bead yang buruk (concave) dan tidak konsisiten dikarenakan nyala bususr yang tidak stabil.

2. Pada bagian weld metal nilai kekerasan terendah dihasilkan oleh gas pelindung $\mathrm{CO}_{2} 100 \%$ yaitu $186.46 \mathrm{HV}$ dan komposisi gas pelindung $\mathrm{Ar}+\mathrm{CO}_{2}(90 \%+10 \%, 80 \%+20 \%$, dan $75 \%+25 \%)$ tidak terdapat perbedaan yang signifikan.

3. Bertambahnya jumlah $\mathrm{CO}_{2}$ pada komposisi gas pelindung menghasilkan jumlah spatter yang lebih banyak. Komposisi $\mathrm{Ar}+\mathrm{CO}_{2}(90 \%+10 \%)$ menghasilkan level spatter terendah yaitu $1.54 \%$ sedangkan level spatter tertinggi dihasilkan oleh pengelasan dengan gas pelindung $\mathrm{CO}_{2} 100 \%$.

4. Komposisi gas pelindung yang efektif untuk digunakan pada pengelasan GMAW short circuit dengan menggunakan mesin RMD untuk digunakan dan direkomendasikan oleh penulis pada pengelasan GMAW short circuit dengan menggunakan mesin $\mathrm{RMD}$ adalah $\mathrm{Ar}+\mathrm{CO}_{2}(80 \%+20 \%)$ atau $\mathrm{Ar}+\mathrm{CO}_{2}(75 \%+25 \%)$.

\section{DAFTAR PUSTAKA}

[1] H. dan O. Wiryosumarto, Teknologi Pengelasan Logam. Jakarta: Pradnya Paramita, 2000.

[2] S. Widharto, Petunjuk Kerja Las. 2001.

[3] TWI, Welding Inspection WIS5. TWI Ltd, 2006.

[4] S. Kou, Welding Metallurgy Handbook, 2nd ed. New York, USA: John Wiley and Sons, 2002.

[5] W. F. G. L. Kevin dan Stapon, "7 Effects Of Shielding Gas, Arc welding article,” 2007. [Online]. Available: thefabricator.com.

[6] A. K. Lyttle, The ASM Handbook, vol 6, Welding, Brazing, and Soldering. PRAXAIR Inc, 1993.

[7] SAIPEM, “STT vs RMD Welding Process Investigation Report,” 2015. 
[8] Zwick/Role, "Vickers Hardness Test, Hardness Testing." [Online]. Available: http://www.indentec.com/downloads/info_vickers_tes. 